Article

\title{
Barriers to Enhancing Disaster Risk Reduction and Community Resilience: Evidence from the L'Aquila Disaster
}

\author{
Angelo Jonas Imperiale * and Frank Vanclay \\ Faculty of Spatial Sciences, University of Groningen, 9747 AJ Groningen, The Netherlands; \\ E-Mails: a.j.imperiale@rug.nl (A.J.I.), frank.vanclay@rug.nl (F.V.) \\ * Corresponding author
}

Submitted: 20 April 2020 | Accepted: 30 June 2020 | Published: 10 December 2020

\begin{abstract}
Building sustainable and resilient societies is a multidimensional challenge that affects achievement of the 2030 Agenda for Sustainable Development. In crises and disasters, civil protection authorities typically use emergency powers and a command-and-control approach to manage resources and to design and implement disaster management interventions. They centralise knowledge, technologies and responsibilities for prevention, mitigation and monitoring, while stifling the capacities of local communities to reduce disaster risks and impacts. The mechanism they enact leads to a poor understanding of the capacities of local people to learn and transform, and of how community wellbeing, vulnerabilities, and resilience influence disaster risks. The mechanism does not strengthen the role of local communities in disaster risk reduction. Instead, it facilitates disaster capitalism at all levels of society. Drawing on the disaster risk reduction and resilience paradigm and on our analysis of the disaster management interventions conducted before and after the 6 April 2009 earthquake in L'Aquila, Italy, we discuss the main constraints to implementing the four Priority Areas in the Sendai Framework for Disaster Risk Reduction: (1) Understanding risk in its multiple dimensions; (2) strengthening disaster risk governance; (3) investing in disaster risk reduction for resilience; and (4) enhancing preparedness and build back better in response, recovery and reconstruction. We discuss how top-down, emergency-centred civil protection approaches create second disasters, and fail in all four priorities. We suggest that shifts in paradigm and investment are required in disaster management and development practice from centralised civil protection systems to decentralised, socially sustainable community empowerment systems.
\end{abstract}

\section{Keywords}

community development; community wellbeing; corruption; disaster capitalism; disaster governance; elite capture; prevention; reconstruction; social learning; social sustainability; social transformation

\section{Issue}

This article is part of the issue "The Politics of Disaster Governance" edited by Dorothea Hilhorst (Erasmus University Rotterdam, The Netherlands), Kees Boersma (Vrije Universiteit Amsterdam, The Netherlands) and Emmanuel Raju (University of Copenhagen, Denmark).

(C) 2020 by the authors; licensee Cogitatio (Lisbon, Portugal). This article is licensed under a Creative Commons Attribution 4.0 International License (CC BY).

\section{Introduction}

For over 30 years, disasters have not been considered as external to societies, but as multidimensional phenomena that must be understood in the context of socially-produced vulnerabilities and risks (Oliver-Smith, Alcántara-Ayala, Burton, \& Lavell, 2017). This still current understanding reflected a shift in disaster man- agement thinking from the previous 'war approach' to full consideration of the social dimensions of disasters (Perry \& Quarantelli, 2005; Quarantelli, 1998). It also led the United Nations to establish a disaster risk reduction (DRR) and resilience paradigm that should be the basis of all disaster management and development interventions in all countries. This DRR and resilience paradigm advocates reducing vulnerabilities and risks, enacting gen- 
uine community engagement and empowerment, and building local community resilience in disaster management and development practice (International Decade for Natural Disaster Reduction, 1994; United Nations Disaster Relief Organization, 1982; United Nations Office for Disaster Risk Reduction, 2005, 2015). According to the DRR and resilience paradigm, rather than be mere spectators of the activities carried out by others, affected communities should have a role in and responsibility for DRR and resilience; and, rather than be protected from disasters, they must be actively included in and empowered by all planned interventions. Increasing recognition of the role of local communities (and of their risks, vulnerabilities, and resilience) has led to a change in thinking about responsibility for DRR and resilience from a government to a governance approach (Beratan, 2007; Clark-Ginsberg, 2020; Cutter et al., 2008; Gall, Cutter, \& Nguyen, 2014a, 2014b; Parra \& Moulaert, 2016; Tengö, Brondizio, Elmqvist, Malmer, \& Spierenburg, 2014; Tierney, 2012). The governance construct highlights that, beyond traditional government institutions, there is a wide range of diverse national and local actors that have roles and responsibilities in relation to DRR and resilience building (Gall et al., 2014a, 2014b; Tierney, 2012; United Nations Office for Disaster Risk Reduction, 2017).

The theoretical shifts in disaster management thinking - from a war approach to considering the social dimensions of disasters; and from a government to a governance approach-were followed by a shift in disaster management practice from civil defence to civil protection (Alexander, 2002). Although increasing attention has been given in the disaster management literature to the need to engage local communities and facilitate community resilience, the shift from government to governance never truly happened. Discrepancies between theory and practice remain in the way disaster management and development interventions are carried out by States, especially those States that rely on top-down, emergency-centred civil protection systems (Imperiale \& Vanclay, 2019a, 2019b, 2020a, 2020b; Lavell \& Maskrey, 2014). Myths, misconceptions and mistakes persist, especially in the ways civil protection authorities manage the risks and impacts associated with crises and in the ways they interpret the behaviour of local communities (Imperiale \& Vanclay, 2016a, 2019a, 2019b; Tierney, 2003; Tierney, Bevc, \& Kuligowski, 2006). Despite the United Nations Disaster Relief Organization (1982) report, Shelter After Disaster, the Yokohama Strategy (International Decade for Natural Disaster Reduction, 1994), the Hyogo Framework for Action (United Nations Office for Disaster Risk Reduction, 2005), and the Sendai Framework (United Nations Office for Disaster Risk Reduction, 2015), governments and their civil protection agencies still fail to value the contribution of local communities, and instead promote centralized technological command-and-control solutions to the detriment of local people and to their capacities to learn and transform (Clark-Ginsberg, 2020; de la Poterie \& Baudoin, 2015; Gaillard \& Mercer, 2012; Wright, 2016). Furthermore, local risk mitigation and monitoring, essential public services and other forms of support to enhance community wellbeing were gradually dismantled, especially in the most vulnerable and remote regions, where maintaining such services was not considered efficient or politically convenient (de la Poterie \& Baudoin, 2015; Gaillard \& Mercer, 2012; Wright, 2016). As a result, despite the many United Nations declarations, there are still gaps in capacity, knowledge and financing that undermine DRR and resilience outcomes, especially at the local level (United Nations Office for Disaster Risk Reduction, 2017).

In past decades, the disaster governance strategies undertaken by governments and civil protection agencies-i.e. strategies for risk management, financing, community participation, physical planning, and institutional arrangements (see Jha et al., 2010)-have largely not been conceptualised or subject to critical social analysis because disaster management actions were generally seen as morally worthy and the issues they addressed were seen as exceptional rather than normal. Furthermore, media coverage and academic discourse has largely remained trapped in an untheorized consensus that recovery and reconstruction after disaster are good and beyond reproach (de Waal, 2008). There is only limited research on the institutional constraints to genuinely empowering communities and enhancing inclusive social learning and socially sustainable transformation at the local level (Amundsen, 2012; Eriksen et al., 2011; Gall et al., 2014a, 2014b).

This article is part of a larger research project that looked at the social dimensions associated with the 6 April 2009 L'Aquila earthquake and the disaster management interventions carried out before and after the disaster (Imperiale \& Vanclay, 2016a, 2016b, 2019a, 2019b, 2020a, 2020b). The overall project used a wide range of methods, including: action anthropology; participant observation; fieldwork discussions; public forums; focus groups; fieldnotes; surveys; document analysis; media analysis; 37 retrospective, in-depth interviews with key informants; and over 250 interviews with people in local communities undertaken between 2009 and 2018. In this reflection paper, drawing on our analysis of the failures of top-down civil protection approaches (Imperiale \& Vanclay, 2019a, 2019b, 2020a, 2020b) and using Jha et al. (2010), we discuss the main barriers and constraints in typical disaster governance to implementing the four Priority Areas for Action outlined in the Sendai Framework (United Nations Office for Disaster Risk Reduction, 2015): (1) understanding disaster risk in all its multiple dimensions; (2) strengthening disaster risk governance to manage disaster risk; (3) investing in DRR for resilience; and (4) enhancing disaster preparedness for effective response, and to build back better in recovery, rehabilitation and reconstruction (United Nations Office for Disaster Risk Reduction, 2015). At the 
time of writing this article (mid 2020), the Covid-19 pandemic has made understanding the constraints that hinder States from enhancing DRR, building community resilience, and fully aligning their efforts in the four Priority Areas more crucial than ever.

\section{Understanding Disaster Risk (Priority 1) versus denying the Multiple Dimensions of Risk}

To enhance DRR and resilience, the United Nations recommended understanding risk in all its dimensions, specifically vulnerability, capacity, exposure, and hazard characteristics (United Nations Office for Disaster Risk Reduction, 2015). Such an understanding should be organized by a comprehensive risk management strategy that informs all other strategies and disaster management and development interventions. In the L'Aquila Province, before and after the earthquake, there were vulnerabilities, risks, and exposure of persons and assets, but there were also needs, capacities, and knowledge to reduce disaster risks. However, the disaster management interventions that were implemented by the Italian State through its national and local civil protection authorities had only a narrow understanding of disaster risk, and failed to conceive, design and implement appropriate pre-disaster and post-disaster activities, as we describe below.

For several months before the fatal earthquake, an earthquake swarm was threatening the life, health and wellbeing of people in L'Aquila Province (Imperiale \& Vanclay, 2019a). During this time, Giampaolo Giuliani, a scientist working at the Gran Sasso National Laboratories, was making predictions about likely earthquakes. These predictions increased the awareness of the local communities about disaster risk. For some, this increasing awareness was a source of anxiety or concern; for others, it was accompanied by a growing awareness of worsening vulnerabilities in the local built environment. By living in an environment at risk, local people were learning that their hazard exposure and vulnerability were increasing. Therefore, they started to care about safety. They learned how vulnerable people were most at risk, and they felt responsibility towards them. Local schools were often closed as a precaution. During the earthquake swarm, many local people made comments at body corporate meetings about the worsening of cracks in their building. They demanded building inspections and to see civil protection plans, asking for effective strategies to reduce local vulnerability and risks, and to enhance local preparedness and emergency plans. However, instead of responding to community demands and appreciating community resilience, the risk management strategy of the authorities was initially to deny the existence of any risk, and later to reassure people that nothing was going to happen. The only risks they considered were the alleged anxiety and alarmism of the local population, which they argued had to be suppressed (Imperiale \& Vanclay, 2019a).
A press release issued by the Abruzzo civil protection on the morning of 30 March 2009, which was a key piece of evidence in a court case (Imperiale \& Vanclay, 2019a; Tribunale di L'Aquila, 2012), stated that no more tremors were foreseen. Paradoxically, there was a 4.1 earthquake that very afternoon. The press release caused much embarrassment for the national Department of Civil Protection (DCP). Together with the attention Giuliani's predictions were getting, this created unease within the DCP, which led to it convening a meeting of the national Major Risk Commission (MRC) the next day. Rather than listen to local people, the intention of the MRC meeting was to reassure them that everything was under control. This attitude of contempt that the authorities had towards local people was very evident in a recorded phone conversation when the DCP Chief said that the purpose of the MRC meeting was to "shut up any imbecile, [and] calm down any conjectures and worries" (Imperiale \& Vanclay, 2019a). Officially, the MRC scientists were being asked to "carefully analyse the scientific and civil protection issues related to the seismic sequence occurring in L'Aquila Province" (Imperiale \& Vanclay, 2019a; Tribunale di L'Aquila, 2012, p. 94). With this Terms of Reference, the DCP expected that there be a risk assessment only in terms of the likelihood of a strong earthquake in the short term, rather than any consideration of risk in all its multiple dimensions.

The poor state of buildings in L'Aquila and the risks associated with the vulnerabilities of the local built environment were known for at least 20 years (Barberi, Bertolaso, \& Boschi, 2007; Boschi, Gasperini, \& Mulargia, 1995). In the local community, there were other local scientists who, well before the earthquake, played a key role in managing local seismic monitoring stations, and in producing reports and academic papers about the seismic hazard in the region and the vulnerabilities of local buildings. In 1999, a local scientist (De Luca, Marcucci, Milana, \& Sano, 2005) had highlighted the high seismicity of L'Aquila city and the presence of an important amplification factor. None of this knowledge was considered by the DCP and it was actively excluded by the composition and conduct of the MRC (Imperiale \& Vanclay, 2019a).

In the way the MRC meeting was conducted, the assessment of local vulnerabilities and the inclusion of local knowledge and capacities were considered to be irrelevant. The vulnerabilities of the local built environment, especially as noted by local residents, were not considered, and people's requests to see civil protection plans were not answered. The local public health system, municipal services, professional associations, building firms, NGOs, local scientists, and other formal and informal groups and individuals were excluded from assessing and reducing local disaster risk. DRR activities were considered merely as matters of public order and control that required police action, rather than as matters of enhancing community wellbeing and reducing local vulnerabilities. During the MRC meeting, the local civil protection agency was only asked if they were tak- 
ing action against people spreading unfounded rumours. There was no discussion about local civil protection or emergency plans, about the capacities and vulnerabilities of the local health care system, or about any plan to enhance local DRR, or to strengthen community preparedness and resilience (Imperiale \& Vanclay, 2019a). The result of this was that, despite the over-reaction of the State at the national level after the earthquake, at the local level there was complete unpreparedness, as graphically explained by an interviewee:

Nothing, nothing! Do you fully appreciate the significance of nothing [sai che vuol dire niente]?...That night there was an absence of everything. The first ambulances... were to be seen...perhaps only at around 6 am [over 2.5 hours after the earthquake]. There was no water, firefighters were very few...it was a city abandoned unto itself. There was nothing...The city of L'Aquila, on the night of the earthquake, was a city in which who was afraid was afraid, who was not was not, and it went like it went.... It was [a city] totally unprepared...and guess what, even part of the hospital was damaged.

The 6.3 Mw earthquake damaged more than 35,000 buildings, 309 people died, some 1,600 people were injured, and more than 70,000 people were rendered homeless. Analyses of damage (Augenti \& Parisi, 2010) and deaths (Alexander \& Magni, 2013) revealed poor design, poor-quality building materials, and shoddy workmanship. One of the major contributing factors was the inadequacy of the prevailing building codes, and the limited extent to which they were enforced. The (not) surprising outcome was that the newer reinforced concrete frame buildings accounted for $79 \%$ of deaths (Alexander \& Magni, 2013). Eight people died in a student dormitory. Here, the death toll would have been much higher except that many students had left due to their fear of an impending earthquake and their awareness of the increasing vulnerability of the building. This dormitory became a focal point for the outpouring of grief, both real and feigned (“Terremoto dell'Aquila," 2013).

After the earthquake, no risk or impact assessment informed the top-down planning used by national and local civil protection authorities to implement and manage emergency tent camps, temporary housing schemes, disaster rubble, safety measures, demolitions, or reconstruction interventions. All their interventions failed to consider the social dimensions of disaster in the recovery, reconstruction and re-development processes. The lack of any risk or impact assessment led to the design of interventions that did not consider the environmental, social or human rights impacts on community wellbeing. This also led to a lack of consideration of the local vulnerabilities and risks that post-disaster interventions could exacerbate, thus worsening local social exclusion and inequity, leading to a second disaster.

\section{Strengthening Disaster Risk Governance (Priority 2) versus exacerbating Social Exclusion}

Disaster risk governance should be led by "a clear vision, plans, competence, guidance and coordination within and across sectors, as well as participation of relevant stakeholders" at the community, regional, national, and international levels (United Nations Office for Disaster Risk Reduction, 2015, p. 17). This vision should be enabled by effective institutional and participation strategies through which everyone can learn, act, and positively transform towards enhancing DRR and resilience in prevention, preparedness, response, recovery, and reconstruction activities. However, in L'Aquila, the Italian State and its civil protection system used emergency powers and a military-type, command-and-control approach. This approach contained a strict decisionmaking process that was closed to the public, and failed to develop a clear, participatory plan and to adequately coordinate the DRR and resilience activities of all relevant stakeholders. Such an approach perpetuated business as usual and facilitated disaster capitalism at the local and national levels, hindering social learning and transformation towards better DRR and resilience outcomes.

Before the earthquake, the governance strategy of the DCP was to use emergency procedures to rapidly convene the MRC meeting to assess disaster risk in the L'Aquila Province. The strict command-and-control approach meant that the meeting was closed to the public. The conclusions of the MRC scientists were intended to be confidential advice to the DCP and local civil protection authorities. Local scientists, local knowledge and local actors were all excluded. Discussing, designing and implementing participatory plans to reduce local vulnerabilities and risks, and to enhance local community resilience and preparedness, were considered irrelevant (Imperiale \& Vanclay, 2019a).

After the earthquake, a complex set of institutional arrangements and immediate actions were implemented by all levels of government, including the overwhelming militarization of the affected region and the establishment of restricted areas (red zones). The primary governance mechanism was the declaration of a State of Emergency, which was left in place for three years, an extraordinary long time (Khakee, 2009; Venice Commission, 1995). A Department of Command and Control was established and became the extraordinary government of the affected area, which became known as the crater. The State of Emergency accorded the DCP with emergency powers, specifically the power of injunction (i.e., to issue ordinances on behalf of the government) and the power of exception (i.e., derogation of ordinary rules and requirements), in effect giving the DCP the ability to act unilaterally (Imperiale \& Vanclay, 2019b, 2020a).

Use of emergency powers and the command-andcontrol approach does not require engagement of local 
communities. In the short and mid-term response and recovery actions implemented by the $\mathrm{DCP}$, only the local mayors and their trusted technicians were consulted. For the temporary housing scheme that was implemented (i.e., the CASE project), the DCP used a consultationcommand-and-control approach in which all decisions around the project were made by the DCP in consultation with the L'Aquila Mayor and two professionals the Mayor had appointed using emergency procedures. The L'Aquila Council and the local communities were excluded from decision-making related to the emergency tent camps or temporary housing, which was not based on any housing needs assessment (Imperiale \& Vanclay, 2019b, 2020a, 2020b).

After 10 months, the Department of Command and Control was replaced by a new temporary government entity called the Struttura Tecnica di Missione (STM, which means something like 'Technical Support Agency'), which was intended to support the Abruzzo Region President and the L'Aquila Mayor in relation to reconstruction efforts. Amongst some controversy, the then President of the National Association of Building Firms, Gaetano Fontana, was appointed as its coordinator. The STM liaised with the Office of Public Works of the Ministry of Public Infrastructure and Transport. However, from the perspective of local people and the local councils, the change from the Department of Command and Control to the STM did not lead to any fundamental change to the command-and-control approach. Furthermore, a senior staff member in the Office of Public Works was known to have close links to organised crime ("Guglielmi," 2010).

The State granted local political leaders with emergency powers so that they could implement 'urgent measures,' a term that was applied to a wide range of tasks. This did not lead to the strengthening of local democratic governance. Numerous national laws, and prime ministerial, civil protection, regional and mayoral ordinances and decrees enabled derogation from ordinary public procurement and oversight procedures, anti-mafia controls, environmental and public health safeguard policies, and led to disenfranchisement of the local democratic governance. Changes in these ordinances and decrees over time, particularly those related to reconstruction, created differences in treatment, and confusion and alienation for most people, especially the most vulnerable. Underlying interests, the top-down procedures implemented, and the command-and-control approach meant that there was an institutional ignorance and denial about the desirability of community engagement in recovery and reconstruction processes (Imperiale \& Vanclay, 2020a, 2020b).

\section{Investing in DRR for Resilience (Priority 3) versus facilitating Disaster Capitalism}

Public and private investments in DRR and resilience are crucial to enhance "the economic, social, health and cultural resilience of persons, communities, countries and their assets, as well as the environment," and they must be "cost-effective and instrumental to save lives, prevent and reduce losses, and ensure effective recovery and rehabilitation" (United Nations Office for Disaster Risk Reduction, 2015, p. 19). To achieve positive DRR and resilience outcomes, there needs to be an adequate financial strategy to ensure accountability and transparency. This should enable multiple actors across the public and private sectors to enact mutual learning and solid partnerships for shared outreach of DRR and resilience outcomes and follow-up (United Nations Office for Disaster Risk Reduction, 2015). Such partnerships must embrace equity and social inclusion as principles, means and outcomes, and develop strategies to enhance the wellbeing of all members of local communities, especially the most vulnerable. However, before the L'Aquila earthquake, there was no investment in DRR and resilience interventions. After the earthquake, the phenomenal investments in response, recovery, reconstruction, and development activities were not accountable or transparent, nor equitable or inclusive. They were not informed by any DRR and resilience outcomes, by any socially sustainable empowerment strategy, or by any inclusive participation. Furthermore, the activities were hijacked by local and national elites, which facilitated disaster capitalism, worsened social risks (e.g., rentseeking, elite capture, organised crime infiltration and corruption), exacerbated inequity and local vulnerabilities, resulting in a second disaster.

Before the earthquake, many expensive technical reports concerning the vulnerability of the local built environment were produced, but led to no DRR and resilience outcomes. Although these reports cost millions of euros each, they were not co-produced or transformative at the local community level, and they were largely ignored by local and national institutions (Imperiale \& Vanclay, 2019a). After the earthquake, major interventions were funded and implemented without being considered by the Italian Parliament. During the three years of the State of Emergency, the DCP and local authority figures were provided with unlimited access to financial resources, which were made available by the State through the Civil Protection Fund, an emergency fund that can be drawn upon whenever a State of Emergency is declared. There was very little control over use of this fund, and it was automatically topped up. The actions were undertaken using emergency powers, and were covered by state secrecy provisions (Imperiale \& Vanclay, 2019b, 2020a).

Although no-bid contracts had already been criticised as avenues for disaster capitalism (Button \& Oliver-Smith, 2008; Damiani, 2008; Imperiale \& Vanclay, 2020a; Klein, 2007), in L'Aquila local and national authority figures made considerable use of them. Only six days after the earthquake, the government directly allocated $€ 300,000$ to a private foundation to develop the idea of a temporary housing scheme (the CASE project). 
On 28 April 2009, the State allocated $€ 200$ million to ANAS spa (the partly State-owned road construction company) and $€ 100$ million to the Italian railway network. With these funds and the freedom provided by the emergency powers, ANAS and the Italian railway network implemented projects they had previously planned, but without any public scrutiny and without having to adhere to the normal social, environmental and cultural heritage protection arrangements (Imperiale \& Vanclay, 2020a). The cost of the emergency tent camps and hotel accommodation was phenomenal, amounting to around $€ 2.8$ million per day. The cost of the CASE project was also excessive. A lack of transparency and accountability meant that there was inconsistent reporting. For example, the European Court of Auditors (2012) reported that the total cost of the CASE project was $€ 597$ million, equivalent to over $€ 1,648$ per square metre of living accommodation, or $158 \%$ more than the normal market cost for a pre-fabricated apartment, or $27 \%$ more than a normal residential apartment (European Court of Auditors, 2012). Søndergaard (2013), however, reported that the total cost of the CASE project was $€ 809$ million. In an official report about the costs of the post-disaster interventions, the Italian Minister for Territorial Cohesion from 2011 to 2013, Fabrizio Barca (2012), indicated that the total cost was $€ 833$ million (Imperiale \& Vanclay, 2019b).

With the implementation of the State of Emergency, the existing anti-mafia procedures were suspended. In response to journalist questioning about this, a national law decree (Italian Government, 2009) was issued on 28 April 2009 to implement anti-mafia arrangements. However, unlike most other regulatory actions which applied immediately, these anti-mafia provisions only came into force three months later (Italian Government, 2009). Furthermore, the text of the new arrangements was vague and potentially enabled the provisions to be by-passed. In any event, it was all too late: safety measures, shoring-up, demolitions, temporary housing solutions and rubble removal, transport and disposal were already being implemented (Imperiale \& Vanclay, 2020a). At least five firms with known mafia connections had already been engaged in the CASE project implementation (Galullo, 2009; Libera, 2010; Postiglione, 2010). In May 2009, a quarry owned by a local construction firm with alleged links to the mafia was selected as a site for rubble storage, and $€ 10$ million was allocated as payment (Libera, 2010). Funds were directly allocated to influential local building firms to complete the construction of unoccupied apartments to make them ready for use. This was part of a complex housing scheme, called the $A Q$ ethical fund, which was perceived by many as an ad-hoc scheme conceived by local building firms to avoid expropriation of the over 3,000 unoccupied apartments they owned (Imperiale \& Vanclay, 2020a). Moreover, the extent of and speed by which safety measures were implemented in the L'Aquila city centre were phenomenal. In less than 6 months, the whole red zone of L'Aquila city was 'put into safety'. The red zone was carved-up into districts and assigned to various influential local and national building firms. Local authorities made extensive use of no-bid contracts to appoint building firms to demolish buildings, design and implement shoringup solutions, manage disaster rubble, and design reconstruction of public buildings, including schools, churches, and other heritage properties (Imperiale \& Vanclay, 2020a, 2020b).

In relation to implementing safety measures and rubble management, there was an intricate system of corruption, in which payments were made by building companies to bogus consulting firms belonging to local public officials (Orsini, 2016). With the local officials having unrestricted access to the Civil Protection Fund, and not having to provide the State with any official financial statements, as well as a complete lack of monitoring and accountability, this comprised an ideal situation for graft and corruption to flourish. To give some impression of the scale of this, the total cost of the shoring-up solutions and demolitions was over $€ 628$ million. Since the earthquake, there have been many legal actions relating to allegations of fraud, corruption, bribery, and inadequate public administration, which implicated national and local public officers and building firms (Fidone, 2017; Imperiale \& Vanclay, 2019b, 2020a). A European Parliament report (Søndergaard, 2013) and an Italian parliamentary inquiry (Bindi, 2018) confirmed the extensive infiltration by organized crime. In June 2014, a criminal investigation coordinated by the local branch of the national anti-mafia organisation led to the arrests of building entrepreneurs for their linkages to the mafia ("L'Aquila," 2014). A major issue relating to this was that the safety measures implemented drew attention and resources away from reconstruction (Imperiale \& Vanclay, 2020b).

Overall, there was nothing in the financial strategy to prevent disaster capitalism and organised crime from taking hold, or social exclusion and inequity from being exacerbated, instead there were arrangements that enabled the elites to hijack the interventions and for disaster capitalism to flourish. The state secrecy provisions, lack of disclosure, and derogations associated with the State of Emergency, served to hide dubious arrangements, disguise fraud and corruption, and facilitate disaster capitalism and organized crime infiltration (Imperiale \& Vanclay, 2019b, 2020a, 2020b).

\section{Enhancing Preparedness and Build Back Better (Priority 4) versus Top-Down Planning}

Post-disaster interventions are critical opportunities to build back better not only housing and infrastructure, but also more resilient and sustainable societies (United Nations Office for Disaster Risk Reduction, 2015). Building back better can be achieved through ensuring that equitable and universally-accessible preparedness, response, recovery, reconstruction, and development strategies are in place, and that DRR and resilience 
is integrated into development, thus making nations and communities more resilient to disasters (United Nations Office for Disaster Risk Reduction, 2015). In L'Aquila, however, the centralized command-and-control approach adopted by the local and national authorities led to top-down planning that exacerbated local vulnerabilities, risks, and the social pre-conditions of disasters, thus failing to enhance DRR and resilience and to build back better more sustainable and resilient communities.

Before the earthquake, one issue that exacerbated vulnerability in L'Aquila was that the seismic zoning and building codes had not been updated for many decades. Despite scientific knowledge of the high seismicity risk of the L'Aquila area (Boschi et al., 1995; De Luca et al., 2005; Stucchi et al., 2004), in the national seismic classifications issued in 1984 and 2003, L'Aquila was still considered as only being of moderate seismicity (since 1927, see Stucchi, Meletti, Rovida, D’Amico, \& Capera, 2010). Since the end of the 1990s, several studies outlined that many reinforced concrete frame buildings, notably the local hospital, were highly vulnerable because L'Aquila had an outdated building code (Di Pasquale, Dolce, \& Martinelli, 2000; Nuti \& Vanzi, 1998). A consequence of this was that, for many decades, poor quality construction and speculative building had been facilitated. Other issues that exacerbated local vulnerability were: lobbying by builders to influence local urban planning policies; weak local governance; and a poor local culture of planning (Alexander, 2010; OECD, 2013). This is evident in the fact that, in 1951 there were 54,633 inhabitants within 500 hectares of built-up area, whereas in 2001, 68,503 inhabitants lived on over 3,100 hectares of builtup area. While the population increased by $25 \%$, land consumption increased six times (Frisch, 2010). The lax building regulations, overconfidence about the growth potential of the region, and other incentives led to there being around 3,000 unoccupied apartments in the City of L'Aquila at the time of the earthquake.

The earthquake was not used as a window of opportunity to 'build back better,' and it did not lead to any local institutional change in terms of good land utilisation or DRR and resilience. After the earthquake, land consumption increased exponentially. The CASE project alone led to the expropriation of over 6,000 allotments, including over 100 hectares of farmland, causing irreversible damage to local agriculture (Forino, 2015; Frisch, 2010; Imperiale \& Vanclay, 2019b). In August 2011, a new regional law was introduced to address DRR and inform reconstruction. However, rather than be an opportunity to correct the manifestly-inappropriate seismic rating, Regional Law n.28 (Abruzzo Region, 2011) reconfirmed L'Aquila City as being in a moderate seismic zone. Nevertheless, Regional Law n.28 was intended to require the implementation of a process of 'seismic authorization' and monitoring for all restoration work and new building construction. However, arbitrary postponements, orchestrated bureaucratic delays, and various revisions to the law, including the ability to modify the plans after approval, meant that this seismic authorization and monitoring was not effectively implemented.

Rather than facilitate local change and build a culture of DRR and resilience, the top-down planning used by the State exacerbated disaster impacts and local pre-existing vulnerabilities and risks. For example, the management of the emergency shelter arrangements created social fragmentation and exclusion, neglected local community resources, capacities, and resilience, and increased local people's dependence on external assistance (Imperiale \& Vanclay, 2019b). The CASE project was implemented without any community needs assessment, or any environmental, social, or human rights impact assessment. It created urban sprawl and impacts on landscape, water quality, agricultural production, health and wellbeing, further exacerbating social disintegration, anomie, homelessness, the loss of sense of place, depression, and other disaster impacts (Alexander, 2010; Calandra, 2016; Ciccozzi, 2016; Imperiale \& Vanclay, 2019b). Despite its phenomenal cost, the poor quality of construction materials and other deficiencies of the CASE project created dangerous situations, including leaking pipes, water seepage, fires due to faulty electric systems, and the improper use of flammable materials. All this led to over $10 \%$ of the CASE apartments being declared unfit for habitation. This also led to many people being forced to relocate elsewhere, creating further hardship, stress, and psychological trauma. Furthermore, the phenomenal cost of maintenance and the many shortcomings in construction and energy use has meant that the CASE project is an ongoing liability for the local municipality and the residents who have to bear the burden of its inadequacies (Imperiale \& Vanclay, 2019b).

After the earthquake, the State granted local political leaders emergency powers to implement urgent measures including: the identification of existing or new landfill sites for rubble disposal; disaster rubble management; implementation of safety measures and demolitions; design of local reconstruction strategies; and reconstruction of public buildings, including heritage properties (Imperiale \& Vanclay, 2020a). As with the CASE project, these actions were implemented through emergency procedures without any environmental, social, or human rights impact assessments, nor by any assessment of the long-term sustainability of these activities. Very curiously, various national agencies and local authority figures used the emergency powers to implement normal projects, such as the building of a bridge, and the enhancement of local roads and the railway, without having to observe normal procedures for procurement or impact assessment, and without consulting the local councils or local communities (Imperiale \& Vanclay, 2020a).

All disaster rubble was considered and managed as normal urban waste, including otherwise dangerous waste such as sewage from the portable toilets in the tent camps and the rubble from collapsed buildings, even though the rubble would have contained high levels of 
asbestos and other pollutants. The National Law Decree (Italian Government, 2009) allowed all activities related to disaster rubble management to be conducted without regard to anti-mafia controls or the environmental management procedures normally required, such as environmental impact assessment, assessment and monitoring of risk, safety measures, protection of groundwater at waste disposal sites, and public health and safety standards (Imperiale \& Vanclay, 2020a). Shoring-up solutions and demolitions were conducted without respect for local people's human right to property, without adequate consideration of the environmental and social sustainability of these measures in the mid to long term, without any care regarding materials that could have been reused (e.g., historic stones and planks), and without any regard to the possessions of inhabitants (Imperiale \& Vanclay, 2020a, 2020b).

An issue of major concern to local inhabitants was the restoration of local school buildings, and the lack of DRR measures implemented in that process. After the earthquake, across the whole of the crater, 21 schools were classified ' $E$ ' (i.e., uninhabitable), and classes were relocated to temporary buildings. 11 years after the earthquake, none of these schools have been reconstructed, and over 3,600 students (about $60 \%$ of the students in the city) still go to school in temporary buildings (Ciuffini, 2018). Some 23 school buildings were classified ' $B$ ' (temporarily uninhabitable) and were restored through emergency procedures. In January 2017, some students together with their parents and teachers founded the Committee for Safe Schools (Comitato Scuole Sicure) to complain about the vulnerability of these schools and to claim the right to have safer schools. This committee lamented that these schools were poorly restored, without implementing any adequate seismic retrofit. Through a formal Freedom of Information request, the Committee discovered and publicly revealed that the L'Aquila Province was aware of the structural vulnerability of these schools and was deliberately hiding this information. Subsequently, an inquiry of the local newspaper, // Centro, revealed that of 1287 school buildings in the Abruzzo region, only 417 had been assessed for seismic risk. Of these, 391 school buildings (93\%) were unsafe (“Abruzzo," 2017).

Overall, after the earthquake, local and national civil protection authority figures implemented a top-down physical planning strategy through the use of emergency powers and a command-and-control approach. Such a strategy led to top-down planned interventions that did not consider the social dimensions of post-disaster operations. Rather than be considered as windows of opportunity to pursue inclusive social learning and socially sustainable transformation towards better DRR and resilience outcomes, post-disaster interventions did not lead to any positive change at the local level. These interventions perpetuated business as usual, facilitated rentseeking, elite capture, organised crime infiltration, disaster capitalism, and corruption. This exacerbation of social risks worsened local inequity and social exclusion, and, instead of building back better, led to interventions that created further environmental, social, and human rights risks and impacts, exacerbating local pre-disaster vulnerabilities and the social pre-conditions of disaster, therefore resulting in second disasters (Imperiale \& Vanclay, 2019b, 2020a, 2020b).

\section{Conclusion}

We live in a global risk landscape that is characterised by biological, geo-physical, environmental, macroeconomic, technological, societal and geopolitical risks, which, over the last two decades, have been increasing in their extent, intensity and frequency. Earthquakes, abnormal weather events, wildfires, landslides, pandemics, and situations of environmental or social injustice are some of the risks, which, together with other global stressors (e.g., biodiversity loss, climate change, deforestation, desertification, financial crises, globalization, land degradation, migration, resource scarcity, rising sea level), constitute the global risk landscape in which we live. When these risks turn into disasters, they create devastating impacts on local communities, their wellbeing, and their environments. At the time of writing this article (mid 2020), the Covid-19 pandemic has made this global risk landscape more evident than ever. Due to the current global crisis, States must undertake immediate action at community, national, and international levels to reduce the risks. It is all too evident that the four Priority Areas of the Sendai Framework for Disaster Risk Reduction need to be fully implemented: (1) understanding risk in all its multiple dimensions; (2) strengthening disaster risk governance; (3) investing in DRR for resilience; and (4) enhancing preparedness and build back better.

For each Priority Area, this article highlighted the failures of the Italian State and its top-down, emergencycentred civil protection system. What the L'Aquila case showed is that the paternalistic attitude States still have towards local communities is completely inadequate to fully understand the positive and negative social processes within affected communities. These community dynamics can contribute to either reducing or exacerbating disaster risks and impacts at all levels of society. Consequently the positive characteristics of communities should be strengthened while the negative characteristics should be mitigated.

This paternalistic attitude leads decision-makers to consider the sharing of knowledge concerning disaster risks as a source of collective anxiety and/or unjustified alarmism that must be suppressed. It also leads to regarding DRR mitigation and monitoring as mere technical activities that, rather than be everyone's business, are considered to be only the business of the commanderin-charge, and something from which local communities must be kept out of the way. The paternalistic attitude and the command-and-control approach leads to 
the accumulation of knowledge, technologies, resources, and responsibilities only in certain pockets of control, while hindering the broader constituency of society from participating, benefiting, and learning from past failures and the root causes of disasters. All this prevents any chance of understanding the multiple dimensions of risk, building democratic disaster governance, investing in resilience, or facilitating a socially sustainable transformation towards achieving better DRR and resilience outcomes at all levels of society.

As is revealed in most disasters around the world, the top-down, emergency-centred, command-and-control worldview States frequently have leads decision makers to respond to disaster risk by using 'the four stage strategy' that was made famous by the BBC TV series, Yes, Minister (Allen, Lotterby, \& Whitmore, 2016): (1) nothing is going to happen; (2) something is going to happen, but we should do nothing about it; (3) maybe we should do something about it, but there is nothing we can do; and (4) maybe there was something we could have done, but it is too late now. Similar to this Four Stage Strategy, as the L'Aquila disaster clearly revealed, States: deny the existence of any risk; accept the existence of risks but seek to reassure the population that everything is under control; ignore vulnerabilities and the root causes of disasters that must be reduced; and when the disaster occurs, they over-react using centralised, militarytype, top-down arrangements that fail to engage communities, perpetrate business as usual, protect the interests of the elites, and exacerbate the root causes of disaster.

Extrapolating from the L'Aquila situation, it is clear that socially sustainable transformations are needed in the way that States: understand risk in all its multiple dimensions; organise their governance and investments to reduce risks and build resilience; and plan prevention, preparedness, recovery, reconstruction and development interventions to build back better. A switch from centralised, emergency-centred civil protection to more decentralised, socially sustainable community empowerment systems is crucial. Such decentralised community empowerment systems must avoid denying the existence of risk, and over-reacting after disasters. Furthermore, these systems should build a sustainable risk governance at all levels of society. This sustainable risk governance should enhance understanding of the social dimensions of disasters. It should also recognise, engage, and strengthen local people's capacity to learn from local vulnerabilities, social risks and disaster impacts, and to positively transform towards enhancing community wellbeing.

\section{Conflict of Interests}

The authors declare no conflict of interests, however, the lead author indicates that he was born in L'Aquila, he was a resident of L'Aquila mountain region for most of his life, and was present during the night of the 6 April 2009 earthquake.

\section{References}

Abruzzo, nove scuole su dieci a rischio sismico. L'inchiesta de "Il Centro" mette a nudo le promesse della politica: E l'impotenza dei genitori [Abruzzo, nine schools over ten have seismic risk: The inquiry of II Centro exposes the promises of politics: And the powerlessness of the parents]. (2017, September 13). II Fatto Quotidiano. Retrieved from https://www. ilfattoquotidiano.it/2017/09/13/abruzzo-novescuole-su-dieci-a-rischio-sismico-linchiesta-de-ilcentro-mette-a-nudo-le-promesse-della-politicae-limpotenza-dei-genitori-di-fronte-al-pericoloconclamato/3851602

Abruzzo Region. (2011, August 11). Norme per la riduzione del rischio sismico e modalità di vigilanza e controllo su opere e costruzioni in zone sismiche [Rules for the reduction of seismic risk and of monitoring and control over construction work in seismic zones]. (Legge Regionale 11 Agosto 2011, N. 28). Abruzzo: Civil Protection. Retrieved from https://protezionecivile.regione.abruzzo.it/files/ normativaregionale/LR_28_2011.pdf

Alexander, D. (2002). From civil defence to civil protection: And back again. Disaster Prevention and Management, 11(3), 209-213.

Alexander, D. E. (2010). The L'Aquila earthquake of 6 April 2009 and Italian Government policy on disaster response. Journal of Natural Resources Policy Research, 2(4), 325-342.

Alexander, D. E., \& Magni, M. (2013). Mortality in the L'Aquila (Central Italy) earthquake of 6 April 2009: A study on victimisation. PLOS Currents Disasters. https://doi.org/doi:10.1371/50585b8e6efd1

Allen, S., Lotterby, S., \& Whitmore, P. (2016). A victory for democracy [Video file]. Retrieved from https:// www.youtube.com/watch?v=nSXletP5iak\&ab_ channel=Far-RightWatch

Amundsen, H. (2012). Illusions of resilience? An analysis of community responses to change in Northern Norway. Ecology and Society, 17(4). https://doi.org/ 10.5751/ES-05142-170446

Augenti, N., \& Parisi, F. (2010). Learning from construction failures due to the 2009 L'Aquila, Italy, earthquake. Journal of Performance of Constructed Facilities, 24(6), 536-555.

Barberi, G., Bertolaso, G., \& Boschi, E. (2007). Difendersi dai Terremoti: La prevenzione sismica in Italia [Defending oneself from earthquakes: Seismic prevention in Italy]. In F. Barberi (Eds.), Dall'emergenza alla ricostruzione [From emergency to reconstruction] (pp. 15-18). Perugia: Quattroemme.

Barca, F. (2012). La Ricostruzione dei Comuni del Cratere Aquilano: Relazione [The reconstruction of the municipalities of the L'Aquila crater: Report]. Rome: Ministry for Territorial Cohesion. Retrieved from http://www.6aprile.it/wp-content/uploads/2012/ 03/Relazione_Barca_def_16_03.pdf 
Beratan, K. K. (2007). A cognition-based view of decision processes in complex social-ecological systems. Ecology and Society, 12(1). Retrieved from http://www. ecologyandsociety.org/vol12/iss1/art27

Bindi, R. (2018). Relazione conclusiva, Cucommissione parlamentare di inchiesta sul fenomeno delle mafie $e$ sulle altre associazioni criminali anche straniere [Concluding report, Parliamentary Committee of Inquiry on Mafia and other criminal organizations even foreign] (Doc. XXII, N.o 38). Rome: Camera dei Deputati, Senato della Repubblica. Retrieved from http://documenti.camera.it/_dati/leg17/lavori/ documentiparlamentari/IndiceETesti/023/038/ INTERO.pdf

Boschi, E., Gasperini, P., \& Mulargia, F. (1995). Forecasting where larger crustal earthquakes are likely to occur in Italy in the near future. Bulletin of the Seismological Society of America, 85(5), 1475-1482.

Button, G. V., \& Oliver-Smith, A. (2008). Disaster, displacement and employment: Distortion in labor markets in post-Katrina reconstruction. In N. Gunewardena \& M. Schuller (Eds.), Capitalizing on catastrophe: The globalization of disaster assistance (pp. 123-145). Walnut Creek, CA: AltaMira.

Calandra, L. M. (2016). Between perception and reality: Towards an assessment of socio-territorial discomfort in L'Aquila (Central Italy) after the earthquake. Epidemiologia e Prevenzione, 40(2), 72-81.

Ciccozzi, A. (2016). The hazards of reconstruction: Anthropology of dwelling and social health risk in the L'Aquila (Central Italy) post-earthquake. Epidemiologia e Prevenzione, 40(2), 93-97.

Ciuffini, R. (2018, March 14). L'Aquila: Ricostruzione scuole, il cronoprogramma ancora non c'è: La De Amicis non tornerà in centro [L'Aquila: the reconstruction of school, there is still no time schedule: The De Amicis school will not come back to the city centre]. NewsTown. Retrieved from https://news-town.it/ politica/19586-I-aquila-ricostruzione-scuole,-ilcronoprogramma-ancora-non-c-\%C3\%A8.html

Clark-Ginsberg, A. (2020). Disaster risk reduction is not 'everyone's business': Evidence from three countries. International Journal of Disaster Risk Reduction, 43.

Cutter, S. L., Barnes, L., Berry, M., Burton, C., Evans, E., Tate, E., \& Webb, J. (2008). A place-based model for understanding community resilience to natural disasters. Global Environmental Change, 18(4), 598-606.

Damiani, B. (2008). Capitalization of post-9/11 recovery. In N. Gunewardena \& M. Schuller (Eds.), Capitalizing on catastrophe: Neoliberal strategies in disaster reconstruction (pp. 157-172). Plymouth: Altamira Press.

de la Poterie, A. T., \& Baudoin, M. A. (2015). From Yokohama to Sendai: Approaches to participation in international disaster risk reduction frameworks. International Journal of Disaster Risk Science, 6(2), 128-139.

De Luca, G., Marcucci, S., Milana, G., \& Sano, T. (2005). Evidence of low-frequency amplification in the city of L'Aquila, Central Italy, through a multidisciplinary approach including strong-and weak-motion data, ambient noise, and numerical modeling. Bulletin of the Seismological Society of America, 95(4), 1469-1481.

de Waal, A. (2008). Foreword. In N. Gunewardena \& M. Schuller (Eds.), Capitalising on catastrophes (pp. ix-xiv). Lanham, MD: Rowman Altamira.

Di Pasquale, G., Dolce, M., \& Martinelli, A. (2000). Analisi della vulnerabilità: Censimento di vulnerabilità a campione dell'edilizia corrente dei centri abitati, nelle regioni Abruzzo, Basilicata, Calabria, Campania, Molise, Puglia e Sicilia (Progetto Lavori Socialmente Utili) Dipartimento della Protezione Civile, Roma [Analysis of vulnerability: Vulnerability assessment of buildings in the Abruzzo, Basilicata, Calabria, Campania, Molise, Puglia and Sicily regions by sample. Rome: Department of Civil Protection.

Eriksen, S., Aldunce, P., Bahinipati, C. S., D’Almeida, M. R., Molefe, J. I., Nhemachena, C., .. . Ulsrud, K. (2011). When not every response to climate change is a good one: Identifying principles for sustainable adaptation. Climate and Development, 3(1), 7-20.

European Court of Auditors. (2012). The European Union Solidarity Fund's response to the 2009 Abruzzi earthquake: The relevance and cost of operations. Luxembourg: European Court of Auditors. Retrieved from https://www.eca.europa.eu/Lists/ ECADocuments/SR12_24/SR12_24_EN.PDF

Fidone, G. (2017). The conflict against corruption and the pursuit of efficiency in public negotiation in Italy. US-China Law Review, 14(30), 30-45.

Forino, G. (2015). Disaster recovery: Narrating the resilience process in the reconstruction of L'Aquila (Italy), Geografisk Tidsskrift: Danish Journal of Geography, 115(1), 1-13.

Frisch, G. J. (2010). L'Aquila: Non si uccide così anche una città? [L'Aquila: Don't you also kill a city this way?]. Naples: Clean.

Gaillard, J. C., \& Mercer, J. (2012). From knowledge to action: Bridging gaps in disaster risk reduction. Progress in Human Geography, 37(1), 93-114.

Gall, M., Cutter, S. L., \& Nguyen, K. (2014a). Transformative development and disaster risk management. Beijing: Integrated Research on Disaster Risk.

Gall, M., Cutter, S. L., \& Nguyen, K. (2014b). Governance in disaster risk management: integrated research on disaster risk. Beijing: Integrated Research on Disaster Risk.

Galullo, R. (2009, April 17). Abruzzo/Le fissure nel muro che le mafie possono far diventare un nuovo terremoto: Bandi di gara, corruzione e Massimo ribasso [Abruzzo/The cracks in the wall that organized crime can make become a new earthquake: Public procurement, corruption and undercutting]. I/ Sole 24 Ore. Retrieved from http://robertogalullo.blog. ilsole24ore.com/2009/04/17/abruzzo-le-fessurenel-muro-che-le-mafie-possono-far-diventare- 
un-nuovo-terremoto-bandi-di-gara-corruzione-emassimo-ribas/?refresh_ce $=1$

Guglielmi, i lavori e il sogno dell'ANAS [Guglielmi, the works and the dream of ANAS]. (2010, February 20). II Centro. Retrieved from https://www.ilcentro.it/ abruzzo/guglielmi-i-lavori-e-il-sogno-dell-anas1.413069

Imperiale, A. J., \& Vanclay, F. (2016a). Experiencing local community resilience in action: Learning from post-disaster communities. Journal of Rural Studies, 47, 204-219. https://doi.org/10.1016/j.jrurstud. 2016.08.002

Imperiale, A. J., \& Vanclay, F. (2016b). Using social impact assessment to strengthen community resilience in sustainable rural development in mountain areas. Mountain Research and Development, 36(4), 431-442. https://doi.org/10.1659/MRDJOURNAL-D-16-00027.1

Imperiale, A. J., \& Vanclay, F. (2019a). Reflections on the L'Aquila trial and the social dimensions of Disaster Risk. Disaster Prevention and Management: An International Journal, 28(4), 434-445. https://doi.org/ 10.1108/DPM-01-2018-0030

Imperiale, A. J., \& Vanclay, F. (2019b). Commandand-control, emergency powers, and the failure to observe United Nations disaster management principles following the 2009 L'Aquila earthquake. International Journal of Disaster Risk Reduction, 36. https:// doi.org/10.1016/j.ijdrr.2019.101099

Imperiale, A. J., \& Vanclay, F. (2020a). The mechanism of disaster capitalism and failure to build community resilience in post-disaster regions: Lessons learned from the L'Aquila earthquake. Disasters. https://doi. org/10.1111/disa.12431

Imperiale, A. J., \& Vanclay, F. (2020b). Top-down reconstruction and the failure to 'build back better' resilient communities after disaster: Lessons from the 2009 L'Aquila Italy earthquake. Disaster Prevention and Management. https://doi.org/10.1108/ DPM-11-2019-0336

International Decade for Natural Disaster Reduction. (1994). Yokohama strategy and plan of action for a safer world: Guidelines for natural disaster prevention, preparedness and mitigation. Yokohama: IDNDR. Retrieved from http://www.ifrc.org/Docs/ idrl/I248EN.pdf

Italian Government. (2009, April 28). Interventi urgenti in favore delle popolazioni colpite dagli eventi sismici nella regione Abruzzo nel mese di aprile 2009 e ulteriori interventi urgenti di protezione civile [Urgent interventions to support the population hit by seismic events in the Abruzzo region in April 2009 and further urgent civil protection interventions] (Decreto Legge 28 Aprile 2009, N. 39). Rome: Italian Government. Retrieved from https://www.camera. it/parlam/leggi/decreti/09039d.htm

Jha, A. K., Barenstein, J., Duyne, P., Priscilla, M., Pittet, D., \& Sena, S. (2010). Safer homes, stronger communities: A handbook for reconstructing after natural disasters. Washington, DC: World Bank. Retrieved from https://openknowledge.worldbank. org/handle/10986/2409

Khakee, A. (2009). A comparative analysis of emergency powers in Europe. Geneva: Geneva Centre for the Democratic Control of Armed Forces. Retrieved from https://www.files.ethz.ch/isn/99550/pp30_anna_ khakee_emergency_powers.pdf

Klein, N. (2007). The shock doctrine: The rise of disaster capitalism. New York, NY: Metropolitan Books.

L'Aquila, le mani dei casalesi sulla ricostruzione: 7 arresti [L'Aquila the hands of Casalesi on reconstruction: 7 arrests]. (2014, June 25). I/ Centro. Retrieved from https://www.ilcentro.it/l-aquila/l-aquila-le-manidei-casalesi-sulla-ricostruzione-7-arresti-1.335450

Lavell, A., \& Maskrey, A. (2014). The future of disaster risk management. Environmental Hazards, 13(4), 267-280.

Libera. (2010). Dossier Abruzzo: Crepe 6 Aprile 2009 ore 3.32. La fine dell'isola felice [Dossier Abruzzo: The 6 April 2009 3.32am cracks: The end of the happy island]. Avezzano. Retrieved from www.site.it/le testate/_notes/DOSSIER\%20LIBERA\%20web.pdf

Nuti, C., \& Vanzi, I. (1998). Assessment of post-earthquake availability of hospital system and upgrading strategies. Earthquake Engineering \& Structural Dynamics, 27(12), 1403-1423.

OECD. (2013). Policy making after disasters: Helping regions become resilient: The case of postearthquake Abruzzo. Paris: OECD.

Oliver-Smith, A., Alcántara-Ayala, I., Burton, I., \& Lavell, A. (2017). The social construction of disaster risk: Seeking root causes. International Journal of Disaster Risk Reduction, 22, 469-474.

Orsini, A. (2016, March 23). Tangenti puntellamenti: 7 a processo a ottobre, prosciolto Di Gregorio [Bribes for shoring-up solutions: 7 on trial in October, $\mathrm{Di}$ Gregorio acquitted]. AbruzzoWeb. Retrieved from http://www.abruzzoweb.it/contenuti/tangentipuntellamenti-7-a-processo--a-ottobre-proscioltodi-gregorio/594952-4

Parra, C., \& Moulaert, F. (2016). The governance of the nature-culture nexus: Lessons learned from the San Pedro de Atacama case study. Nature and Culture, 11(3), 239-258.

Perry, R., \& Quarantelli, E. L. (2005). What is a disaster? New answers to old questions. Philadelphia, PA: Xlibris Corporation.

Postiglione, A. (2010, March 13). Affari e terremoti: Svelate le trame che hanno ricostruito l'Abruzzo [Deals and earthquakes: The arrangements that have reconstructed Abruzzo revealed]. Verso L'Aquila. Retrieved from https://versolaquila.wordpress.com/2010/03/ $13 /$ svelate-le-trame-che-hanno-ricostruitoI\%E2\%80\%99abruzzo

Quarantelli, E. L. (Ed.). (1998). What is a disaster? Perspectives on the question. London: Routledge. 
Søndergaard, S. (2013). Feedback report on the factfinding mission to Italy, 2013. Brussels: European Parliament. Retrieved from http://www.europarl. europa.eu/meetdocs/2009_2014/documents/cont/ dt/1007/1007699/1007699en.pdf

Stucchi, M., Akinci, A., Faccioli, E., Gasperini, P., Malagnini, L., Meletti, C., . . Gasperini, P. (2004). Redazione della mappa di pericolosità sismica prevista dell'ordinanza PCM del 20 marzo 2003, n 3274, All. 1, Rapporto Finale [Map of seismic risk issued by the Prime Minister Ordinance on 20 March, 2003, n.3724, Annex 1, Final Report]. Milan: Istituto Nazionale di Geofisica e Vulcanologia. Retrieved from http://zonesismiche.mi.ingv.it/documenti/ rapporto_conclusivo.pdf

Stucchi, M., Meletti, C., Rovida, A., D’Amico, V., \& Capera, A. A. (2010). Seismic actions and site effects 1.2: Historical earthquakes and seismic hazard of the L'Aquila area. Progettazione Sismica, 1(3), 23-34.

Tengö, M., Brondizio, E. S., Elmqvist, T., Malmer, P., \& Spierenburg, M. (2014). Connecting diverse knowledge systems for enhanced ecosystem governance: The multiple evidence base approach. Ambio, 43(5), 579-591.

Terremoto dell'Aquila, il prefetto rideva e fingeva commozione per le vittime [The L'Aquila earthquake, the prefect was laughing and pretending emotion towards the victims]. (2013, January 19). II Fatto Quotidiano. Retrieved from https://www. ilfattoquotidiano.it/2013/01/19/prefetto-iuratorideva-e-fingeva-commozione-per-vittime-delterremoto-dellaquila/474340

Tierney, K. (2003). Disaster beliefs and institutional interests: Recycling disaster myths in the aftermath of 9-11. In L. Clarke (Ed.), Terrorism and disaster: New threats, new ideas (pp. 35-51). Amsterdam: Elsevier.

Tierney, K. (2012). Disaster governance: Social, political, and economic dimensions. Annual Review of Environment and Resources, 37, 341-363.

Tierney, K., Bevc, C., \& Kuligowski, E. (2006). Metaphors matter: Disaster myths, media frames and their con- sequences in Hurricane Katrina. Annals of the American Academy of Political and Social Science, 604(1), 57-81.

Tribunale di L'Aquila. (2012). Sentenza nella causa penale contro Barberi Franco, De Bernadinis Bernardo, Boschi Enzo, Selvaggi Giulio, Calvi Gian Michele, Eva Claudio, Dolce Mauro. Tribunale di L'Aquila, L'Aquila, Italy. L'Aquila: Tribunale di L'Aquila. Retrieved from http://www.magistraturademocratica.it/mdem/ qg/doc/Tribunale_di_LAquila_sentenza_condanna_ Grandi_Rischi_terremoto.pdf

United Nations Disaster Relief Organization. (1982). Shelter after disaster: Guidelines for assistance. Geneva: Office of the United Nations Disaster Relief Co-Ordinator.

United Nations Office for Disaster Risk Reduction. (2005). Hyogo Framework for Action 2005-2015: Building the resilience of nations and communities to disasters. Geneva: United Nations Office for Disaster Risk Reduction. Retrieved from http://www.unisdr.org/ 2005/wcdr/intergover/official-doc/L-docs/Hyogoframework-for-action-english.pdf

United Nations Office for Disaster Risk Reduction. (2015). Sendai Framework for Disaster Risk Reduction 2015-2030. Geneva: United Nations Office for Disaster Risk Reduction. Retrieved from http://www.preventionweb.net/files/43291_ sendaiframeworkfoDRRandresilienceen.pdf

United Nations Office for Disaster Risk Reduction. (2017). Local government powers for disaster risk reduction: A study on local-level authority and capacity for resilience. Geneva: United Nations Office for Disaster Risk Reduction. Retrieved from https://www.unisdr.org/campaign/resilientcities/ assets/toolkit/documents/LG\%20Powers\%20for\% 20DRR_2017_Final_20170531.pdf

Venice Commission. (1995). Emergency powers, science and technique of democracy. Strasburg: European Commission for Democracy to Law.

Wright, K. (2016). Resilient communities? Experiences of risk and resilience in a time of austerity. International Journal of Disaster Risk Reduction, 18, 154-161.

\section{About the Authors}

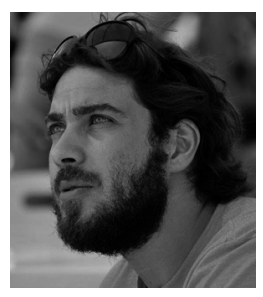

Angelo Jonas Imperiale has a PhD in Rural Sociology and Disaster Risk Reduction from the University of Groningen, The Netherlands. His expertise is in the fields of Social Impact Assessment, Disaster Risk Reduction, reconstruction, sustainable development in vulnerable regions, community resilience and social sustainability.

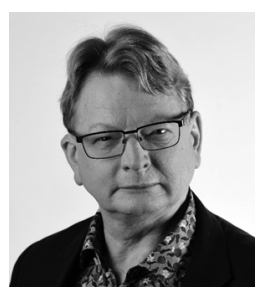

Frank Vanclay is Professor of Cultural Geography and Director of the Urban and Regional Studies Institute in the Faculty of Spatial Sciences at the University of Groningen, The Netherlands. He writes in a number of fields of research, including social impact assessment, social license to operate, business and human rights, community engagement, and related topics. 